\title{
Analysis of the Possibilities of Protecting Human Capital in the Context of the Covid-19 Epidemic
}

\author{
Viktor Orekhov ${ }^{1},{ }^{*}$ Oleg Rukodaynyy ${ }^{2}$, Dmitry Kicha ${ }^{2}$, Denuts Moroga ${ }^{3}$ \\ ${ }^{1}$ International Institute of Management LINK, Russia \\ ${ }^{2}$ Peoples' Friendship University of Russia (RUDN University) \\ ${ }^{3}$ Institute of Physical Rehabilitation, Russia \\ "Email:vvorehov@yandex.ru
}

\begin{abstract}
The work is devoted to the urgent problem of protecting human capital (HC) in the context of an epidemic threat. The study aims to analyse the possibilities of activating the use of vaccination to protect the $\mathrm{HC}$ of Russia in the conditions of the Covid-19 epidemic. The subject of the study is a system of factors affecting people's motivation to activate selfdefence in an epidemic threat. An online survey of 600 respondents aged 35-44 and over 55 years is used as the primary research method. Most of them (73-81\%) acquired immunity to Covid-19, including 30-34\% were ill, and the rest were vaccinated. This means that it is essential to ensure sufficient immunity of inclusive groups of the population at this stage of the epidemic, particularly those who require revaccination and for whom vaccines have not been developed before. Only $1.1 \%$ fell ill with Covid-19 after vaccination and were hospitalised among the respondents. A set of factors that need to be taken into account to build effective communication with the population has been identified, in particular, the main doubts of the population regarding vaccination, sources of information that are most trusted by people, as well as those that raise doubts about the need for vaccination. It is shown that the losses of the $\mathrm{HC}$ of Russia from Covid-19 lead to a loss of GDP of more than 15 billion euros over the life cycle of lost workers. Insurance companies have developed relatively inexpensive (€12-24) insurance programs in case of complications after vaccination. The majority of respondents (60\%) showed interest in such programs. State support could increase their attractiveness to the population and significantly contribute to the activation of vaccination. The study results can be used to develop programs for saving $\mathrm{HC}$ and countering epidemics, in particular, through vaccination.
\end{abstract}

Keywords: Covid-19, Human capital, Vaccination, Epidemic, Complications after vaccination, Risk management, Insurance.

\section{INTRODUCTION}

As a result of the Covid-19 pandemic, humanity has lost more than five million people [1]. In Russia, the pandemic claimed 270 thousand people by the end of November 2021 [2] or $0.18 \%$ of the country's population.

Russia was one of the first to develop and test an effective vaccine against Covid-19. This gave rise to the hope that one of the most massive pandemics of humanity would be successfully defeated [3]. However, the reality turned out to be much more complicated. The fourth wave of morbidity at the end of 2021 surpassed the previous waves in severity, and it is difficult to predict the prospects for the end of the pandemic.

One of the main problems is that the vaccination rate in Russia lags behind developed countries by more than half [4]. At the end of November 2021, the proportion of the fully vaccinated population in Russia was $39 \%$, and the vaccination rate did not exceed $0.27 \%$ of the population per day [2].

The public's confidence in vaccination, which is lower in Russia than in other countries, requires analysis. The speed of creating vaccines without sufficient scientific confirmation of their characteristics has given rise to the opinion that they are not reliable 
enough. The Internet has served as a favourable environment for the spread of speculation, which has led to increased distrust.

The main area of activity in the fight against Covid19 is moving into management, economics [5] and marketing. The State has begun to introduce measures to stimulate vaccination. In Moscow, people over 65 y.o. are given gift sets or a cash payment of $€ 120$.

But Covid-19 is not the last epidemic threat. In the future, the occurrence of even more dangerous infectious diseases is not excluded. Therefore, the development of effective methods to combat epidemics, including increasing confidence in vaccination, is extremely relevant [6] since they provide reliable protection of human capital and the country's population.

Epidemics are not only a medical and social, but also an economic problem [5]. The pandemic "became the trigger for another global economic crisis" [7]. Thus, according to the World Bank, Russia's GDP by PPP in 2020 decreased by $\$ 150$ billion compared to 2019 . link [8]. The reduction of human capital will also lead to significant losses of GDP and for several decades to come. This is especially relevant because the resources of human capital growth in Russia are declining [9].

The purpose of this work is to analyse the possibilities of activating the use of vaccination to protect Russia's human capital from the Covid-19 epidemic.

\section{REVIEW OF PUBLICATIONS}

To activate the use of vaccination, it is crucial to understand the reasons for the refusal of a significant part of Russian citizens from vaccination. To this end, we will consider the arguments of various authors regarding the reluctance of the population to get vaccinated.

In the production of vaccines, Sputnik $\mathrm{V}$ and AstraZeneca use genetically modified adenoviruses as a basis. In the late $90 \mathrm{~s}$, research on gene therapy using adenoviruses was suspended for several years due to the death of several patients [10]. As it turned out, the reason was an excessive dose of adenovirus. Now this problem has been solved, but the use of adenoviruses requires a comprehensive check of the harmlessness of the vaccine.

Complex technical problems arise in the manufacture of complex genetic vaccines in tens of millions of doses since there were practically no productions of this type in Russia until recently.

One of the problematic factors in the vaccination organisation is the lack of Western vaccines on the Russian market. According to a January 2021 survey on the VKontakte social network, $23 \%$ of respondents are ready to be vaccinated with a foreign-made vaccine and pay for it [11].

An international opinion poll conducted by Morning Consult [12] among 75,000 respondents in fifteen countries on October 5-11, 2021, showed that Russia is still among the leaders in the number of those who do not want to be vaccinated against Covid-19 - 28\% of respondents (the USA is in second place - 18\%). The following reasons for the negative attitude towards vaccination in adults were noted: $39 \%$ were concerned about side effects, $28 \%$ were conducted clinical trials too quickly, $14 \%$ were not sure of the effectiveness of vaccines; distrust of manufacturers, low risk of infection and principled rejection of vaccinations $-5 \%$ each.

In countries that have vaccinated more than $3 / 4$ of the population, the pandemic continues. Different infections require different levels of vaccination to achieve population immunity. So for measles, it is $95 \%$ [11]. While in Russia, they are guided by the bar - at least $80 \%$, but apparently, the level of $90-95 \%$ will be required [13].

It should be noted that Covid-19 selectively affects people of different age groups [14], [15]. Mortality among older people is many times higher. As of October 2021, $86 \%$ of the number of deaths from Covid-19 in Moscow are people over the age of 60 [16].

\section{RESEARCH METHODOLOGY}

The paper uses a problem-oriented approach - based on a meta-analysis of publications and surveys, the main problems affecting consumers' attitudes to vaccination are identified.

Methods of questioning, analysis of communications with the population and promotion of vaccination are also used. An online survey was conducted using a questionnaire developed using the Yandex-Vzglyad system to form a behavioural model of the Russian population in a pandemic.

The study was aimed primarily at human capital, that is, at able-bodied people [17], therefore, one of the samples was made up of people aged 35-44 years. In Russia, the age of workers reaches 60 years and more, and since these are the most vulnerable people to the disease, a group over the age of $55(55+)$ was selected as the second sample. The number of respondents was: 200 people aged 35-44 years and 400 people aged $55+$

The statistical error of the survey results with a $95 \%$ confidence probability for values in the area of $50 \%$ of the measuring range is $5 \%$ for the group aged over 55 years and 7\% for the group 35-44 years. For values about $10 \%$ of the range - about 1.6 times less and for values about $2 \%$ of the range -3.5 times less. The sample is not random and is shifted to the contingent 
Table 1. Incidence of Covid-19 respondents, including considering vaccination (Russia, \%)

\begin{tabular}{|l|c|c|}
\multicolumn{1}{|c|}{ Variants of the Covid-19 disease state } & $35-44$ years old & $\begin{array}{c}\text { More than } 55 \\
\text { years }\end{array}$ \\
\hline Did not infected with Covid-19 & 69.9 & 65.7 \\
\hline Benign diseased with Covid-19 & 24.2 & 26.2 \\
\hline Benign diseased with Covid-19, several times & 3.5 & 1.5 \\
\hline Diseased with Covid-19 with hospitalisation & 0.5 & 4.0 \\
\hline Severe diseased with Covid-19 (not priorly vaccinated) & 1.0 & 2.5 \\
\hline $\begin{array}{l}\text { Diseased with Covid-19 with hospitalisation during the vaccine validity period } \\
\text { (no earlier than 30 days after vaccination and no later than 6 months) }\end{array}$ & 0.5 & 0.0 \\
\hline $\begin{array}{l}\text { Severe diseased with Covid-19 with hospitalisation during the vaccine validity } \\
\text { period }\end{array}$ & 0.5 & 0.25 \\
\hline
\end{tabular}

using electronic communication channels, which is more typical of the population group that makes up human capital.

\section{STUDY RESULTS}

\subsection{Investigation of the epidemic situation and protection against infection}

To understand the epidemic situation, a study was conducted of the proportion of respondents who suffered from Covid-19 disease of varying severity on 20.11.2021, considering the impact of vaccination. The survey results are shown in Table 1.

$70-66 \%$ of respondents were not infected with Covid-19 (the first figure refers to the group of 35-44 years). They were benign diseases, including repeatedly, - 28\%; they were diseased with hospitalisation - 2.5$6.4 \%$, including $1-2.5 \%$ in a severe form of the disease. The proportion of people who easily suffered Covid-19 in the two age groups does not differ, but hospitalised in the older group is 2.5 times more.

The most important direction of immunisation of the population is vaccination. The analysis results on the issue of attitudes to vaccination are given in Table 2 . The proportion of vaccinated is $43-47 \%$, which corresponds to the statistical data for this period $(47 \%)$ [4]. Thus, approximately $73-81 \%$ of the population acquired immunity, including $30-34 \%$ of those who were diseased.

Another important indicator is the effectiveness of the vaccine. According to the survey, despite vaccination, 3 out of 600 people fell ill with Covid-19 and were hospitalised (Table 1). The share of such respondents, out of the number of vaccinated, is $1.1 \%$.

Respondents who had Covid-19 also did not all acquire sufficient immunity and were ill repeatedly, including $3.5 \%$ in the $35-44$ year group and $1.5 \%$ in the $55+$ group. This is $12 \%$ and $4.3 \%$, respectively, in

Table 2. Respondents' attitude to vaccination against Covid-19 (\%)

\begin{tabular}{|l|c|c|}
\multicolumn{1}{|c|}{ A variant of the attitude to Covid-19 vaccination } & $35-44$ years old & $\begin{array}{c}\text { More than } 55 \\
\text { years }\end{array}$ \\
\hline Vaccinated, there were no severe complications & 40.9 & 44.5 \\
\hline Vaccinated, there were severe complications & 2.0 & 2.2 \\
\hline Vaccination is contraindicated for medical reasons & 4.0 & 7.5 \\
\hline Plan to get vaccinated & 15.8 & 10.6 \\
\hline Don't plan to get vaccinated unless I have to & 9.9 & 10.1 \\
\hline Will not be vaccinated categorically & 14.3 & 10.1 \\
\hline Finally undecided & 13.3 & 15.0 \\
\hline
\end{tabular}


Table 3. The means of protection and insurance used by respondents against Covid-19 (\%)

\begin{tabular}{|l|c|c|}
\hline Used Covid-19 protection devices & $35-44$ years old & $\begin{array}{c}\text { More than } 55 \\
\text { years }\end{array}$ \\
\hline Availability of insurance against the disease & 1 & 1.3 \\
\hline Covid-19 testing & 1 & 2.5 \\
\hline Ambulatory or hospital treatment & 3 & 8.2 \\
\hline Taking medications at home & 12.9 & 10.4 \\
\hline Covid-19 protection is not implemented & 44.6 & 24.5 \\
\hline Working mostly remotely & 31.7 & 40.0 \\
\hline Covid-19 Vaccination & 40.6 & 46.2 \\
\hline Minimal stay in crowded places & 51.5 & 65.5 \\
\hline Regular wearing of the mask in crowded places & & 10.9 \\
\hline
\end{tabular}

relation to the number of patients. This is significantly more than the proportion of those who did not receive immunity after vaccination. Still, in the case of vaccination, this was determined by a more severe disease (with hospitalisation).

$14 \%$ of people aged $35-34$ and $10 \%$ over 55 categorically do not want to be vaccinated. However, the proportion of those who have not been ill, have not been vaccinated and do not plan to be vaccinated is 11 $8.5 \%$, respectively, significantly less than indicated in [12].

The survey results of respondents regarding the use of various means of protection against Covid-19 are given in Table 3 . According to them, the sum of the means of protection used, implementing a risk reduction strategy, is $94 \%$, risk rejection is $78 \%$, risk acceptance is $27 \%$, and risk transfer (insurance) is $1.1 \%$.

\subsection{Reasons for the low level of confidence in vaccination against Covid-19}

The questionnaire included a block of questions about the reasons for the negative attitude to vaccination in Russia; results are given in Table 4. The main doubts of the population regarding vaccination are as follows: the development of the vaccine was carried out too quickly $(38-33 \%)$, there is a risk of severe side effects $(30-25 \%)$, if the vaccination is harmless, there should be significant insurance $(26 \%)$, there is no confidence in the effectiveness of vaccines (24\%). Comparing the responses received with similar reasons in the Morning Consult survey [12] shows that the main reasons for doubts are approximately the same.

The sources of information that raise the most significant doubts about the need for vaccination (Table

Table 4. Respondents' doubts about Covid-19 vaccination (\%)

\begin{tabular}{|l|c|c|}
\hline \multicolumn{1}{|c|}{ Options for doubts about Covid-19 vaccination } & $35-44$ & $\begin{array}{c}\text { More than } \\
55\end{array}$ \\
\hline Good health, and there will be no severe disease without vaccination & 8.9 & 4.7 \\
\hline There is doubt about the quality of the Covid-19 vaccine production in Russia & 9.9 & 9.6 \\
\hline Health features do not allow vaccination & 7.4 & 11.6 \\
\hline It's hard to believe in what is being reported regarding vaccination & 16.7 & 17.8 \\
\hline $\begin{array}{l}\text { If vaccination is harmless, then there should be significant insurance in case of } \\
\text { complication }\end{array}$ & 26.1 & 26.0 \\
\hline There is no confidence in the effectiveness of vaccination & 23.7 & 25.0 \\
\hline There is a danger that there may be severe side effects after vaccination & 29.6 & 25.2 \\
\hline The development of a vaccine was carried out too quickly & 38.0 & 33.1 \\
\hline
\end{tabular}


Table 5. Sources of information causing distrust of Covid 19 vaccination (\%)

\begin{tabular}{|l|c|c|}
\hline \multicolumn{1}{|c|}{ Sources of information causing distrust of Covid-19 vaccination } & $35-44$ & $\begin{array}{c}\text { More than } \\
55\end{array}$ \\
\hline Unconvincing information in the Russian mass media & 33.1 & 32.4 \\
\hline It is difficult to find data on the level of complications or deaths from Russian vaccines & 20.1 & 15.3 \\
\hline Examples of the negative effects of vaccines are given on social networks and the Internet & 25.2 & 30.9 \\
\hline My friends, colleagues who have a negative attitude to vaccination & 17.3 & 18.8 \\
\hline I personally know people who, after vaccination (during its validity), severely diseased & 16.8 & 14.6 \\
\hline Doctors whose opinion I know do not recommend vaccination & 9.9 & 10.1 \\
\hline
\end{tabular}

5) are unconvincing information in the Russian media (33\%), negative examples in social networks and the Internet $(25-31 \%)$ and lack of information about the level of complications or death of people in Russia after vaccination (20-15\%). This point is all the more relevant because a significant number of respondents (17-15\%) note that they personally know people who became infected with Covid-19 during the vaccination period and were seriously ill.

At the same time, it should be borne in mind that each person has several dozen personal acquaintances, which creates the effect of replicating the negative influence of this factor. Doctors who do not recommend vaccination also have a significant negative impact (about 10\%)

The unsuccessful implementation of communication with the population through the marked communication channels leads to a higher distrust of vaccination in Russia than in other European countries.
It is necessary to develop ways to improve communications to remedy the situation. It is essential to know which population trusts sources of information to do this. The results of the corresponding survey are presented in Table 6.

It can be seen that the most trusted are reputable doctors - $42-45 \%$, acquaintances and statistics, which is quite logical. Social networks, the Internet, domestic and foreign media are among the least convincing channels of information $-9-14 \%$.

\subsection{Covid 19 Vaccination Incentive Programs}

For the information in the media to be convincing, it must be based on facts supported by arguments. First, a convincing accounting system for complications should be debugged, which follows from Table 5. And if there are complications from vaccination, they must be compensated or insured, which will convincingly perform a motivating function.

Table 6. Sources of information about vaccination trusted by respondents (\%)

\begin{tabular}{|l|c|c|}
\hline \multicolumn{1}{|c|}{ Trusted sources of information about Covid-19 vaccination } & $\begin{array}{c}35-44 \text { years } \\
\text { old }\end{array}$ & More than 55 \\
\hline Reputable doctors & 41.9 & 44.7 \\
\hline My family members, friends and colleagues & 36.5 & 27.7 \\
\hline Statistics and survey data & 21.7 & 26.2 \\
\hline Vaccine Developers and Manufacturers & 16.3 & 22.2 \\
\hline The country's leaders & 10.3 & 18.3 \\
\hline Foreign sources of information, World Health Organisation & 9.4 & 13.8 \\
\hline Russian mass media & 10.9 & 10.6 \\
\hline Social networks, Internet, blogs & 9.4 & 9.9 \\
\hline
\end{tabular}


For example, Rosgosstrakh offers a personal insurance program, "Immunity without risk", in case of problems after any vaccination, including Covid-19. The cost of the program is $€ 12$ (or $€ 22$ ). The insurance amount is $€ 12,050$. In case of complications resulting from vaccination during hospitalisation, the client is paid $€ 24$ for each day of treatment, up to 30 days, and in case of death - $€ 6,000$.

The characteristics of this project can be used to assess the planned probability of insured events. Suppose the insurer expects to spend about $50 \%$ of the money received on insurance payments. In that case, when selling 10,000 policies, he/she will receive $€ 120,500$, of which about $€ 60,000$ will be for payments (the rest of the funds will go to administration, promotion, rehabilitation of patients and profitability). As shown above, approximately $1 \%$ of those vaccinated will be hospitalised. Each of them will receive approximately $€ 540$, which will amount to $€ 54,000$. The remaining $€ 6,000$ will go to pay for one fatal case, the probability of which will be about $0.01 \%$.

To assess the interest of Russian citizens in insurance services of this type, a survey was conducted in which respondents were asked to evaluate the acceptability of various cost and size of payments programs for them. The survey results are shown in Table 7.

The financial viability of these programs was based on the above characteristics of the "Immunity without Risk" program. The most popular (23-16\%) is the least expensive program worth $€ 12$. The second segment of popularity with a share of about $14 \%$ arises in the program area worth $€ 60$. In total, $60 \%$ of respondents were interested in insurance programs. It seems that the use of insurance programs of this type can create a significant incentive for the vaccination of citizens, especially older people who are most vulnerable to Covid-19 and for whom incentives are of great importance.

For comparison, the incentive program for Moscow pensioners costs $€ 120$, which is significantly more than the minimum insurance against complications after vaccination. Even the insurance of all Russian citizens who have not yet been vaccinated will cost about 500 million euros, which is immeasurably less than the cost of Covid-19 treatment or loss of human capital.

Human life is priceless, but significant financial resources are required to protect against coronavirus and to use the example of human capital losses, it is possible to assess which funds are appropriate to use. Based on the fact that by now 270 thousand people have died from Covid-19 in Russia, and 86\% [16] of them are over 60 years old, we will get that 38 thousand people under the age of 60 have died.

According to the IMF, Russia's nominal GDP per capita in 2021 amounted to $\$ 11.3$ thousand. With the share of people employed in the economy equal to about $50 \%$, everyone's contribution to GDP is $\$ 22.6$ thousand. Accordingly, the irretrievable loss of GDP due to the labour force reduction resulting from Covid-19 amounts to $\$ 860$ million per year. These losses should be accounted for about half of the employee's work cycle or 20 years. Thus, Russia's human capital losses amount to at least $\$ 17$ billion ( $€ 15$ billion). This is a minimum estimate since the epidemic is still ongoing, and there are also losses of the human capital of citizens over the age of 60. It is appropriate to make expenditures of this level to protect human capital from the Covid-19 epidemic and treatment and rehabilitation [18] from the consequences of the disease.

Returning to a more general view of pandemics, we note that although this work was carried out in Russia, however, the results obtained can be applied in other

Table 7. Respondents' preferences for insurance against complications after Covidvaccination (\%)

\begin{tabular}{|c|c|c|c|c|}
\hline \multicolumn{2}{|c|}{$\begin{array}{c}\text { Options for insurance programs against complications after Covid-19 vaccination } \\
\text { Has already been vaccinated or has been diseased, and there is no point in being } \\
\text { insured }\end{array}$} & $\begin{array}{c}35 \text { years } \\
\text { old }\end{array}$ & $\begin{array}{c}\text { More than } \\
55\end{array}$ \\
\hline \multicolumn{2}{|c|}{ Under no circumstances will I be vaccinated } & 15.3 & 14.6 \\
\hline The cost of insurance & Payment upon hospitalisation & Payment in case of death & & 16.6 \\
\hline$€ 12$ & $€ 600$ & $€ 6,000$ & 23.2 & 16.3 \\
\hline$€ 24$ & $€ 1,080$ & $€ 24,000$ & 15.8 & 17.5 \\
\hline$€ 36$ & $€ 1,260$ & $€ 72,000$ & 7.4 & 10.9 \\
\hline$€ 60$ & $€ 1,800$ & $€ 145,000$ & 13.8 & 15.3 \\
\hline
\end{tabular}


countries, with a correction in price indicators characteristic of these states [19]. This approach is even more critical for preparing for potential threats of a higher level of danger that are not excluded in the future.

\section{CONCLUSIONS}

Sociological studies have been conducted among citizens aged 35-44 and over 55 years, and based on them, ways to activate the use of vaccination to protect the human capital of Russia in the face of epidemic threats have been proposed.

The analysis showed that most respondents (73$81 \%$ ) acquired immunity to Covid-19, including 30$34 \%$ after an illness, and the rest were vaccinated. This means that it is essential to ensure sufficient immunity of inclusive groups of the population at this stage of the epidemic, particularly those who require revaccination and for whom vaccines have not been developed before.

Only $1.1 \%$ of respondents fell ill with Covid-19 after vaccination and were hospitalised, which can be used as a convincing argument to activate vaccination. They did not acquire sufficient immunity after the first Covid-19 disease and were benignly diseased again - $12 \%$ and $4.3 \%$ in the groups of 35-44 years and 55+, respectively.

The factors that need to be considered to build effective communication with the population to activate vaccination, in particular:

- 30-25\% of respondents are afraid of side effects, $24 \%$ are not sure of the effectiveness of vaccines;

- reputable doctors (43\%) and statistical and survey data (22-26\%) enjoy high confidence of the population;

- distrust of vaccination is caused by: inconclusive information in the Russian media (33\%), lack of information about the level of complications from vaccines (20-15\%), personal acquaintance with people who were severely diseased with Covid-19 during the vaccination validity period (17-15\%).

According to a minimum estimate, the calculated data showed that the loss of Russia's human capital due to Covid-19 leads to a loss of GDP of about 15 billion euros over the life cycle of lost able-bodied workers.

Insurance companies have developed relatively inexpensive (about $€ 12-24$ ) insurance programs in case of complications after vaccination. Most respondents $(60 \%)$ are attracted to such programs. State support could increase their importance for the population and significantly contribute to the activation of vaccination.

\section{ACKNOWLEDGMENTS}

The reported study was funded by RFBR. Project number 19-29-07328.

\section{REFERENCES}

[1] Coronavirus disease (COVID-19) Weekly Epidemiological Update and Weekly Operational Update. World Health Organisation, 2021. Retrieved from: https://www.who.int/emergencies/diseases/novelcoronavirus-2019/situation-reports

[2] COVID-19 Dashboard by the Center for Systems Science and Engineering (CSSE) at Johns Hopkins University (JHU), 2021. Retrieved from: https://origin-coronavirus.jhu.edu/map.html

[3] Society and the pandemic: experience and lessons of fighting COVID-19 in Russia [Obshchestvo i pandemiya: opyt i uroki bor'by s COVID-19 v Rossii], Moscow, 2020, 744 p. Retrieved from: https://publications.hse.ru/mirror/pubs/share/direct/ 414121642.pdf

[4] Coronavirus vaccinations (COVID-19). Our World in Data. Retrieved from: https://ourworldindata.org/covid-vaccinations

[5] The COVID-19 pandemic. Biology and economics. Special issue: information and analytical collection: [Text] / Edited by D.E.N. Mizintseva M.F. [Pandemiya COVID-19, Biologiya i ekonomika. Special'nyj vypusk: informacionnoanaliticheskij sbornik: [Tekst] / Pod redakciej d.e.n. Mizincevoj M.F.] // VINITI RAS, M., Pero Publishing House, 2020, p. 66.

[6] V.I. Starodubov, F.N. Kadyrov, O.V. Obukhova et al., The impact of the Covid-19 coronavirus on the situation in Russian healthcare [Vliyanie koronavirusa Covid-19 na situaciyu v rossijskom zdravoohranenii], M., Central Research Institute of Organisation and Informatisation of Healthcare. Version 1.0 [CNII organizacii i informatizacii zdravoohraneniya. Versiya 1.0], 2020.

[7] G.A. Shcherbakov, The impact and consequences of the Covid-19 pandemic: socio-economic dimension [Vliyanie i posledstviya pandemii Covid -19: social'no-ekonomicheskoe izmerenie] // MID (Modernisation. Innovation. Development) [MIR (Modernizaciya. Innovacii. Razvitie)] 12(1) (2021) 8-22. DOI: https://doi.org/10.18184/2079$\underline{4665.2021 .12 .1 .8-22}$

[8] GDP, PPP (current international \$). Retrieved from:

https://data.worldbank.org/indicator/NY.GDP.MK TP.PP.CD?end=2019\&most_recent_year_desc $=$ fal se\&start=1990\&view $=$ chart

[9] Olga S. Prichina, Viktor D. Orekhov, Yulia V. Evdokimova, Olesya G. Kukharenko, Marina V. 
Kovshova. Evolution of Key Factors and Growth Potential of Human Capital. International Journal of Innovative Technology and Exploring Engineering (IJITEE) ,Vol. 8, Issue 7, 2019.

[10] The Death of Jesse Gelsinger. 20 Years Later. Science History Institute. - 2019. URL: https://www.sciencehistory.org/distillations/thedeath-of-jesse-gelsinger-20-years-later

[11] A.V., Torkunov, S.V. Ryazantsev, V.K. Levashov et al., The COVID-19 pandemic: Challenges. Consequences. Counteraction: [monograph] [Pandemiya COVID-19: Vyzovy, posledstviya, protivodejstvie: [monografiya]] / A.V. Torkunov, S.V. Ryazantsev, V.K. Levashov [et al.], M.: Publishing house "Aspect Press", 2021.

[12] P. Shelburne, Across the Globe. Rates of Vaccine Skepticism Have Stalled. Morning Consult, 2021. Retrieved from: https://morningconsult.com/global-vaccinetracking/

[13] The Cabinet of Ministers of the Russian Federation announced a desirable indicator of collective immunity of 90-95\% [V kabmine RF zayavili o zhelatel'nom pokazatele kollektivnogo immuniteta v 90-95\%], Interfax. Retrieved from: https://www.interfax.ru/russia/802250

[14] LC. Okell, R. Verity, OJ. Watson, S. Mishra, P. Walker, C. Whittaker et al., Have deaths from COVID-19 in Europe plateaued due to herd immunity? Lancet 395(10241) (2020) e110-1. Retrieved from: https://doi.org/10.1016/S0140$\underline{6736(20) 31357-X}$

[15] P. Poletti, M. Tirani, D. Cereda et al., Age-specific SARS-CoV-2 infection fatality ratio and associated risk factors. Italy. February to April 2020. Euro Surveill 25(31) (2020) pii=2001383. DOI: https://doi.org/10.2807/15607917.ES.2020.25.31.2001383

[16] Moscow operational headquarters: $86 \%$ of those who died from covid are over 60 years old [Opershtab Moskvy: $86 \%$ umershih ot kovida starshe 60 let], IA Regnum, 2021. Retrieved from: https://regnum.ru/news/3396825.html

[17] V.D. Orekhov, O.S. Prichina, A.V. Blinnikova, E.A. Panfilova, E.S. Shchennikova, Indicative diagnostic of the educational component of human capital based on mathematical modelling, Opción, Año 35, VE, Especial 20 (2019) 2337-2365. Retrieved from: $\underline{\text { https://world- }}$ evolution.ru/pdf/1_2019 106_IndicativeDiagnostic softheeducational.pdf
[18] L. Brugliera, A. Spina, P. Castellazzi et al., Rehabilitation of COVID19 patients, J Rehabil Med 52(4) (2020) jrm00046. DOI: https://doi.org/10.2340/16501977-2678

[19] M.B. Selgado, A.Yu. Abramov, D.I. Kicha, J.A. Zuenkova, The double diseases burdens trends in Ethiopia: covid-19 aggravate the burdens of diseases and the health system. Problems of social hygiene, public health and history of medicine, Russian journal 29(S1) (2021) 813-817. 